\section{(2) OPEN ACCESS}

\title{
Diagnostic difficulties in obturator hernia: a rare case presentation and review of literature
}

\author{
Tharun Ganapathy Chitrambalam 다, Pradeep Joshua Christopher, \\ Jeyakumar Sundaraj, Sundeep Selvamuthukumaran
}

General Surgery, SRM Institute of Science and Technology, Kattankulathur, India

Correspondence to Dr Tharun Ganapathy Chitrambalam; tharungc@srmist.edu.in

Accepted 12 August 2020
D) Check for updates

(c) BMJ Publishing Group Limited 2020. Re-use permitted under CC BY-NC. No commercial re-use. See rights and permissions. Published by BMJ.

To cite: Chitrambalam TG, Christopher PJ, Sundaraj J, et al. BMJ Case Rep

2020:13:e235644

doi:10.1136/bcr-2020-

235644

\section{SUMMARY}

Hernia arising from obturator canal is rare and it contributes to about less than $1 \%$ of incidence of all hernias. Diagnosing an obturator hernia clinically is a challenging one and nearly impossible. These hernias usually present as an intestinal obstruction as more than $50 \%$ of obturator hernias goes in for strangulation. Here, we report an unusual presentation of an obturator hernia in a 70-year-old woman who presented to emergency room with acute abdomen and uncomplicated reducible inguinal hernia. Radiological imaging showed obstructed inguinal hernia while on diagnostic laparoscopy, a strangulated and perforated obturator hernia of Richter's type was seen in addition to an uncomplicated inguinal hernia. Obturator hernia, although very rare, is associated with high morbidity and mortality as it is often underdiagnosed as in our case. Laparoscopy bailed us out from missing out a perforation from an occult obturator hernia.

\section{BACKGROUND}

Obturator hernia is the protrusion of both intraperitoneal or extraperitoneal contents through the obturator canal. ${ }^{1}$ Incidence of obturator hernia is about $0.73 \%$ of all hernias. ${ }^{2}$ Obturator hernia typically affects women, elderly, multiparous, emaciated and those with increased intra-abdominal pressure. ${ }^{3}$ It is never externally visible nor palpable, so it is often undiagnosed or unsuspected. The obturator hernia is most often the Richter's type, which can be a diagnostic challenge as focal strangulation of the bowel can progress to gangrene with or without overt signs of intestinal obstruction. ${ }^{4}$ Richter's hernia is a type of abdominal hernia in which only part of the circumference of the bowel is entrapped and strangulated in the hernial orifice. The segment of the engaged bowel is nearly always the lower portion of the ileum. ${ }^{5}$

\section{CASE PRESENTATION}

A 70-year-old woman was brought to the emergency room with uncomplicated reducible swelling in the right inguinal region for the past 3 years with sudden onset of pain over the swelling for 3 days. Pain was severe, gripping in character and constant which was relieved partly on flexion of the thigh. No history of any medical illness nor any previous surgeries. On physical examination, the patient was moderately nourished and built. Her heart rate was 102 beats/min and blood pressure was 130/70 mm
Hg. Abdomen was soft, not distended with diffuse tenderness present over lower abdominal quadrants with no guarding or rigidity. On local examination, a swelling of size $4 \times 3 \mathrm{~cm}$ was seen in the right inguinal region which was reducible with expansile impulse on coughing.

\section{INVESTIGATIONS}

Ultrasonogram of the abdomen revealed a possible right inguinal/femoral hernia with features of obstruction, and advised CT correlation. CT scan of the abdomen was done subsequently which showed a $3 \times 3 \mathrm{~cm}$ defect in the right inguinal region with herniating bowel loops and overcrowding of ileal loops over the defect with free fluid noted around the ileal loops suggestive of obstructed inguinal hernia as seen in figure 1 .

\section{TREATMENT}

On a diagnosis of obstructed inguinal hernia, patient was posted for diagnostic laparoscopy and proceeded. After insufflation and creating pneumoperitoneum figure 2, overcrowding of small bowel loops was seen in right inguinal region and pelvis with localised bilious collection of $50 \mathrm{~mL}$ in favour of early perforative peritonitis. On releasing the adhesions and bowel loops, a $3 \times 3 \mathrm{~cm}$ defect was noted in the right inguinal region with viable bowel loops. On further release, $1.5 \times 1.0 \mathrm{~cm}$ defect was noted in the obturator canal with perforation of entrapped bowel loop of Richter's type seen. Laparotomy was done and a $1 \mathrm{~cm}$ perforation in terminal ileum with unhealthy edges was noted $20 \mathrm{~cm}$ from ileocaecal junction as seen in figure 3. Thorough lavage was given. Perforation site resection and anastomoses were done in two layers. Anatomical repair of both the defects was done. Obturator defect was closed

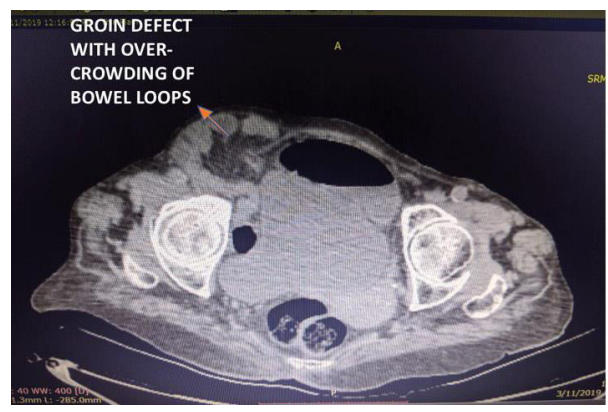

Figure $1 \mathrm{CT}$ image depicting groin defect with overcrowding of bowel loops. 


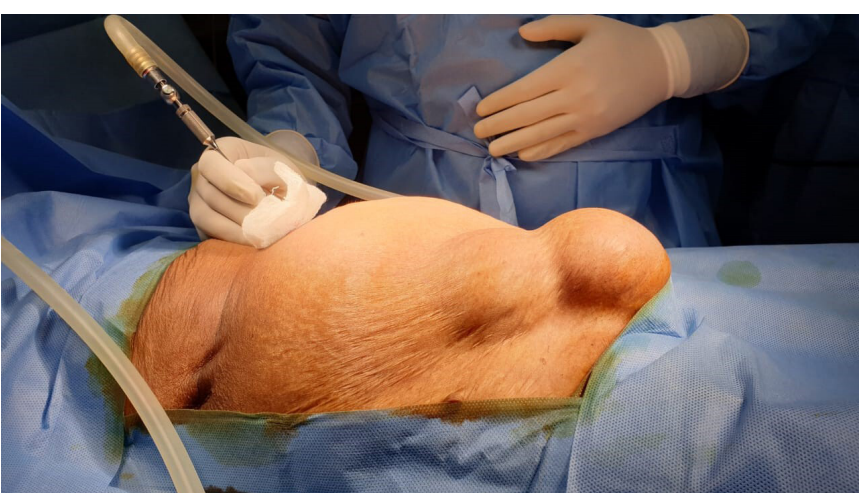

Figure 2 Hernial orifice filling with $\mathrm{CO}_{2}$ after insufflation with veress needle.

at first primarily with 1-polypropylene followed by closure of inguinal defect with interrupted 1-polypropylene sutures as depicted in figure 4.

\section{OUTCOME AND FOLLOW-UP}

The patient tolerated the procedure well with nil postoperative complications. Orals were started on postoperative day 4 after good bowel sounds, escalated to soft solids and discharged on postoperative day 7 . The patient was periodically followed up for a period of 1 year who remained asymptomatic.

\section{DISCUSSION}

Obturator hernia is the protrusion of abdominal viscera through obturator canal in which the obturator nerve and vessels pass. This hernia is about six to nine times more common in women than men due to their broader triangular pelvis and greater transverse diameter. It affects women of around 70-90 years of age, the reason being attributed to atrophy of the preperitoneal fat around the obturator vessels in the canal thereby predisposing hernia formation and hence the name 'little old woman's hernia'. ${ }^{3}$ The major risk factors for obturator hernia are chronic obstructive pulmonary disease, chronic constipation and ascites. Diagnosing an obturator hernia at the earliest is very difficult as it usually presents with non-specific signs and symptoms. Although it is a rare abdominal hernia, the mortality rate is as high as $70 \%$. Major clinical symptoms are due to intestinal obstruction like abdominal pain, distension, nausea, vomiting and constipation.

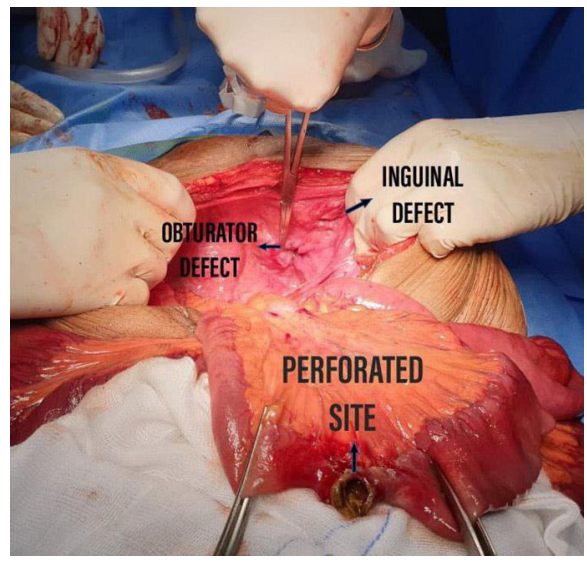

Figure 3 Obturator and inguinal defects with perforated ileum on laparotomy after adhesiolysis.

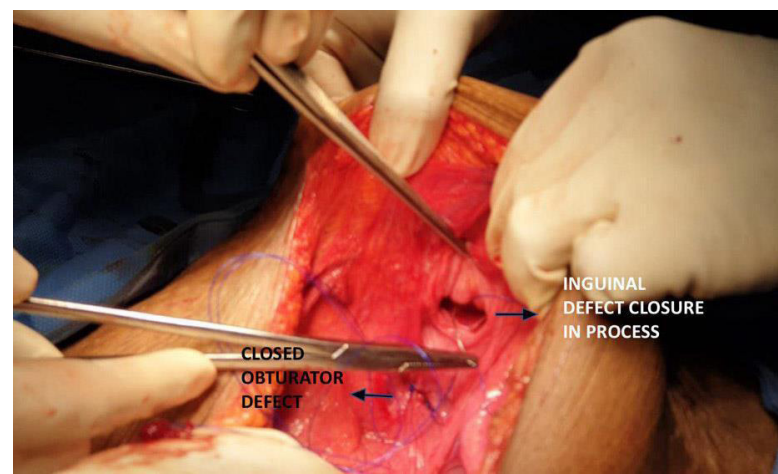

Figure 4 Picture taken after obturator defect closure, while closure of inguinal defect is in process as labelled in figure.

They may also have recurrent attacks of intestinal obstruction in the past with or without a palpable mass in the groin. ${ }^{6}$

Emergency CT scanning could lead to rapid diagnosis and early surgical intervention and thus optimising the outcome. The use of CT scan in detecting obturator hernia was first reported by Meziane et al in 1983. ${ }^{7}$ The common CT scan finding is herniated loop of distal small bowel extending through the obturator foramen between the pectineus and obturator externus muscles. In incarcerated hernia, CT scan shows associated bowel loop dilatation in the abdomen. Since the use of CT scan, preoperative diagnosis rate was improved from $43 \%$ to $90 \%$ in some reports. ${ }^{8}$ However, it is not always possible to diagnose all obturator hernias using CT of the abdomen as seen in our case. Diagnostic laparoscopy serves as a tool in diagnosing and treating occult, suspected and missed obturator hernias on imaging. In our institution, we routinely practice and advocate laparoscopic method for uncomplicated groin hernias including suspected obturator hernias without bowel complications due to advantages like diagnostic accuracy of occult hernias, lesser postoperative pain and other complications. But in this case scenario, due to perforated ileum with peritonitis on laparoscopy and the need for resection and anastomosis, we converted to open surgical approach. Open approach with lower midline is considered the most preferred by many authors as it gives good exposure to the obturator ring and also aids in performing bowel resections when required. ${ }^{9}$ In view of peritonitis in this case, mesh (nonabsorbable or absorbable) was not employed for further reinforcement as non-absorbable meshes have higher chances of mesh rejection and absorbable meshes can get dissolved in the presence of bacterial infection.

\section{Learning points}

Obturator hernia, although very rare, is associated with high morbidity and mortality.

- It is often underdiagnosed as in our case; the preoperative finding of hernia was because of the inguinal hernia with no bowel obstruction and it was an obturator hernia which did not show up clinically was strangulated with a perforated bowel of Richter's type within it. The same could have been easily missed if an inguinal approach had been followed. Laparoscopy bailed us out from missing out a perforation from an occult obturator hernia.

- Laparoscopy should be considered as a tool of choice in cases of an occult obturator hernia and unclear hernias arising from the myopectineal orifice of Fruchaud. 
Twitter Pradeep Joshua Christopher @15j012

Contributors TGC is the major contributor of this study. Study design, data analysis, interpretation, drafting, critical revision and final approval of the article were done by him and he is completely accountable for the research work. PJC, Dr Jeyakumar Sundaraj and SS have helped in planning and reporting, extending administrative support, technical writing and proofreading.

Funding The authors have not declared a specific grant for this research from any funding agency in the public, commercial or not-for-profit sectors.

Competing interests None declared.

Patient consent for publication Obtained.

Provenance and peer review Not commissioned; externally peer reviewed.

Open access This is an open access article distributed in accordance with the Creative Commons Attribution Non Commercial (CC BY-NC 4.0) license, which permits others to distribute, remix, adapt, build upon this work non-commercially, and license their derivative works on different terms, provided the original work is properly cited and the use is non-commercial. See: http://creativecommons.org/ licenses/by-nc/4.0/.

\section{ORCID iD}

Tharun Ganapathy Chitrambalam http://orcid.org/0000-0003-4644-5550

\section{REFERENCES}

1 Lien W-C. Obturator Hernia: The "Little Old Lady's Hernia". J Med Ultrasound 2014;22:96-8.

2 Susmallian S, Ponomarenko O, Barnea R, et al. Obturator hernia as a frequent finding during laparoscopic pelvic exploration: a retrospective observational study. Medicine 2016;95:e4102

3 Sá NC, Silva VCM, Carreiro PRL, et al. Rare case of incarcerated obturator hernia: case report and review of literature. Int I Surg Case Rep 2017;37:157-60.

4 Yokoyama Y, Yamaguchi A, Isogai M, et al. Thirty-Six cases of obturator hernia: does computed tomography contribute to postoperative outcome? World I Surg 1999;23:214-7

5 Tito WA, Allen WCJB HN, Condon RE, eds. Richter and Littre hernia. 3rd edn. Philadelphia: Lippincott, 1989: 305-10

6 Kulkarni SR, Punamiya AR, Naniwadekar RG, et al. Obturator hernia: a diagnostic challenge. Int J Surg Case Rep 2013;4:606-8.

7 Nishina M, Fujii C, Ogino R, et al. Preoperative diagnosis of obturator hernia by computed tomography. Semin Ultrasound CT MR 2002;23:193-6.

8 Liao C-F, Liu C-C, Chuang C-H, et al. Obturator hernia: a diagnostic challenge of smallbowel obstruction. Am J Med Sci 2010:339:92-4.

9 Hodgins N, Cieplucha K, Conneally P, et al. Obturator hernia: a case report and review of the literature. Int J Surg Case Rep 2013;4:889-92.

Copyright 2020 BMJ Publishing Group. All rights reserved. For permission to reuse any of this content visit

https://www.bmj.com/company/products-services/rights-and-licensing/permissions/

BMJ Case Report Fellows may re-use this article for personal use and teaching without any further permission.

Become a Fellow of BMJ Case Reports today and you can:

- Submit as many cases as you like

Enjoy fast sympathetic peer review and rapid publication of accepted articles

Access all the published articles

Re-use any of the published material for personal use and teaching without further permission

Customer Service

If you have any further queries about your subscription, please contact our customer services team on +44 (0) 2071111105 or via email at support@bmj.com.

Visit casereports.bmj.com for more articles like this and to become a Fellow 